\title{
Anita Gostomska
}

Uniwersytet Gdański

\section{Ponowoczesne podróże Dubravki Ugrešić}

W pierwszej dekadzie dwudziestego pierwszego wieku postmodernizm jako kategoria służąca opisywaniu świata coraz częściej wydaje się anachroniczny ${ }^{1}$. Towarzysząca mu polifonia, ewokowana przez implikowane jego naturą rozliczne wewnętrzne sprzeczności, sprawia, że wzbudza on zrozumiałą w świetle dotychczasowej polskiej recepcji krytycznej niechęć. W świecie zachodnim dyskusja postmodernistyczna, początkowo także obfitująca w nieporozumienia, zdążyła już złagodnieć, tracąc jakby swój pierwotny impet. W Polsce niegdyś wywoływała gwałtowne spory, w których nie brakowało niesprawiedliwych diagnoz, a nawet "gołosłownych inwektyw". Obecnie można odnieść wrażenie, że ciężar dawnych debat, być może na skutek postulowanych niegdyś analizy i rzetelnego namysłu, samoistnie przeniósł się $\mathrm{w}$ inne rejony socjokulturowych, $\mathrm{w}$ tym literaturoznawczych dociekań ${ }^{2}$. Tym bardziej zasadne wydaje się pytanie o przydatność postmodernizmu w rozważaniach nad twórczością pisarki wykraczającej poza wskazane tutaj ramy czasowe.

1 W niniejszym szkicu pojęcia "postmodernizm”, ,postmoderna” i „ponowoczesność” traktowane są jako tożsame.

2 Zob. A. Zeidler-Janiszewska, R. Kubicki, Uporzadkowana postmoderna. Wprowadzenie do koncepcji Wolfganga Welscha, w: W. Welsch, Nasza postmodernistyczna moderna, przeł. R. Kubicki, A. Zeidler-Janiszewska, Warszawa 1998, s. XIII, XXII. 
Początki jej kariery przypadają na schyłek lat siedemdziesiątych dwudziestego wieku, kiedy zasłynęła jako autorka zbioru opowiadań, będących czymś nowym w literaturze chorwackiej, a także w odniesieniu do pisanych jeszcze podczas studiów książeczek dla dzieci. Opowiadania wydane w kolejnym tomiku oraz dwie powieści z lat osiemdziesiątych przynoszą Dubravce Ugrešić prawdziwą popularność wśród czytelników i uznanie krytyki, przekładające się m.in. na prestiżowe nagrody $\mathrm{w}$ dziedzinie literatury. Diametralna odmiana losu pisarki, biorącej także czynny udział w życiu środowiska akademickiego Zagrzebia, wiąże się z wybuchem wojny domowej na Bałkanach. Rok 1991 to początek tułaczki, dla której tłem były wydarzenia wojennego konfliktu. Pierwsze wyjazdy z niepodległej Chorwacji można jednak traktować jako wynik przypadku, kolejne, począwszy od 1993 roku, to efekt sekwencji wzajemnych reakcji, jakie zaszły w tych latach na przestrzeni kilkunastu miesięcy. U podstaw negatywnych zmian leży stanowisko Ugrešić wobec agresywnego nacjonalizmu, pozostającego $\mathrm{w}$ tamtym czasie oficjalnym sposobem sprawowania władzy przyczyniającym się do intensyfikacji przemocy. Publikacja na łamach niemieckiej prasy esejów kontestujących ówczesne realia polityczne Chorwacji pociągnęła za sobą charakterystyczne dla państw postjugosłowiańskich żądania publicznego określenia narodowej tożsamości. Kategoryczna odmowa pisarki skończyła się natychmiastowym pomówieniem o "jugoslawizm” i brak patriotyzmu. Ku jej zaskoczeniu także kręgi uniwersyteckie, z którymi była przez szereg lat związana zawodowo, wycofały swe poparcie. Niebawem, prześladowana zarówno w domu (listownie i telefonicznie), jak i na ulicy, anonimowo szkalowana w prasie, została sama. Społeczny ostracyzm, na jaki skazała się swoją bezkompromisową postawą, sprzyjał podjęciu decyzji o opuszczeniu kraju, który jej ojczyzną pozostał wyłącznie nominalnie. Wykorzystując pierwszą okazję do wyjazdu, Dubravka Ugrešić zainicjowała wówczas wędrówkę, która trwa nadal i która może posłużyć jako pretekst do rozmyślań o specyficznym podróżowaniu na przełomie wieków, w obliczu ustrojowych transformacji, dokonujących się w Europie Środkowej, a także współczesnych przemian kulturowych o charakterze globalnym.

Ekspatriacja, zdaniem niektórych całkowicie dobrowolna, była symbolicznym przełomem. Moment bezpowrotnego rozstania z Jugosławią i konieczność kontynuacji włóczęgi katalizują uczucia, dla których najlepszym ujściem staje się esej, felieton, a później złożone, silnie naruszające autonomię świata fikcyjnego powieści, będące w głównej mierze świadectwem ponowoczesnego wyczerpania podmiotowego bytu. W odróżnieniu od ludycznego wariantu postmodernizmu, dominującego w twórczości Ugrešić w latach osiemdziesiątych, teksty, powstające pod wpływem wrażeń wynie- 
sionych z rozpadającego się kraju i doświadczeń zdobytych podczas drogi w nieznane, reprezentują model tragiczny postmodernistycznej podmiotowości artystycznej3 ${ }^{3}$ Trauma wojny, piętno banicji, pamięć jako rezerwuar boleśnie nieuchronnych wspomnień przyczyniają się do nasilenia wcześniejszego nihilizmu, czyniąc ton wypowiedzi niemal autodestrukcyjnym.

Przesłanie intelektualne czy estetyka utworów opublikowanych przez pisarkę po 1991 roku nie są jedynym wyznacznikiem relacji jej twórczości do światowego postmodernizmu ${ }^{4}$. Południowosłowiańscy literaturoznawcy znacznie wcześniej dostrzegali postmodernistyczny charakter prozy Dubravki Ugrešić, odnotowując przy tym konsekwentnie podtrzymywaną oryginalność stylu ${ }^{5}$. Już w okresie kształtowania się świadomości ideowo-artystycznej formacji, pisarstwo Ugrešić wykazuje wiele cech wspólnych z dorobkiem pokolenia jugosłowiańskich postmodernistów, co ona sama - wyposażona w wiedzę z zakresu teorii i historii literatury oraz ogromną erudycję - wykorzystuje do prowadzenia wyrafinowanej gry z krytyką. Tłumaczy to złożoność jej postmodernistycznych narracji, poddawanych zabiegom permanentnej relatywizacji; istotą wspomnianej zabawy jest nieustanna oscylacja pomiędzy zjawiskami przypisywanymi zwyczajowo tradycji czy kanonicznym ujęciom literatury a strategiami i chwytami proponowanymi przez postmodernistów. Wyjaśnia także, dlaczego dialogiczne napięcie antynomicznych układów można uznać za specyfikę twórczości Dubravki Ugrešić.

3 Por. B. Czapik-Lityńska, Anarchistyczno-nihilistyczna podmiotowość Dubravki Ugrešić. Przyczynek do portretu postmodernistycznej ironistki, w: Świat przez pryzmat Ja. Teorie i autobiograficzne rekonesanse, t. 1, red. B. Gontarz, M. Krakowiak, Katowice 2006, s. 52-53.

4 B. Czapik-Lityńska, opierając się na dotychczasowych ustaleniach chorwackiej i polskiej slawistyki, bez cienia wątpliwości klasyfikuje Dubravkę Ugrešić jako pisarkę „,zzasu postmoderny i postmodernistycznej aury”, która „włącza się w literaturę feministyczną [...], drąży problematykę tożsamości i podmiotowości w rozmaitych wariantach [...], jest na sposób Rorty'ego pragmatyczna i racjonalistyczna, nie hipostazuje, nie idealizuje, ani tym bardziej nie utopizuje. Wprowadza postmodernistyczne chwyty i strategie (zwielokrotnienie, powtórzenie), gra gatunkami, konwencjami, stylami. Dekonstruuje dawną «wielką narrację» i dawną literaturę. Kolejne książki Ugrešić są ciągle propozycjami zaskakującymi, lecz nieodmiennie proponują pasjonującą "przygodę duchową", wyrazisty model myślenia krytycznego, prowokującego, anarchizująco-nihilizującego". Zob. tamże, s. 50-51.

5 Do grona badaczy, którzy w Dubravce Ugrešić widzą pisarkę postmodernistyczną, zaliczyć można m.in.: Slobodana Prosperova Novaka, Dubravko Jelčicia czy Krešimira Nemeca. Zob. S. Prosperov Novak, Povijest hrvatske književnosti. Od Baščanske ploče do danas, Zagreb 2003, s. 597; D. Jelčić, Povijest hrvatske književnosti, Zagreb 2004, s. 584; K. Nemec, Povijest hrvatskog romana od 1945. do 2000. godine, Zagreb 2003, s. 320. O postmodernistycznym charakterze prozy Ugrešić i jej znaczeniu dla literackiej sceny byłej Jugosławii w latach osiemdziesiątych wspomina także: Leksikon hrvatskih pisaca, ur. D. Fališevac, K. Nemec, D. Novaković, Zagreb 2000, s. 741 oraz Leksikon hrvatske književnosti. Zob. V. Bogišić, L. Čale Feldman, D. Duda, I. Matičević, Leksikon hrvatske književnosti, Zagreb 1998, s. 292-293. 
W kontekście autobiograficznego przekazu, w obrębie realizowanych wariantów postmodernistycznej prozy, najciekawszy wydaje się aspekt nomadycznej świadomości słabego podmiotu. Pisarka, która fundamentalną zasadą praktyki artystycznej czyni prawo negacji, odpowiada ironią na krępujące w swej jawności tożsamościowe dylematy. Jej życiowa postawa wpisuje się jednak $\mathrm{w}$ „kategorie poznawczo metaforyzujące dzisiejszą przestrzeń społeczną"; początek, koniec, czas, granica, ograniczenie, teraźniejszość i przyszłość, zogniskowane wokół pojęć ",domu” i „,nie-domu" ${ }^{6}$, niezależne od bałkańskiego konfliktu, mogą służyć jako narzędzia opisu uchodźczej rzeczywistości. Ponowoczesne przemieszczenia w interesujący sposób realizują się na materiale empirii pierwszej postmodernistycznej wojny w Europie ${ }^{7}$. Wątpliwymi beneficjentami procesu tranzycji ${ }^{8} \mathrm{w}$ byłej Jugosławii są nomadzi, którzy pozbawieni perspektyw, niepewni celu, zdezorientowani w czasie i przestrzeni, poruszają się w labiryncie obcych światów. Tym, co odróżnia ich od wychodźców czy osiedleńców, jest pokonywanie odległości, przemierzanie terytoriów bez zakreślania granic czy wyznaczania centrum. Droga nomady nie ma początku ani końca, jest wypełnianiem otwartej przestrzeni; reterytorializacja jest zarazem deterytorializacją ${ }^{9}$. Nomadyzm, twórczo artykułowany przez Dubravkę Ugrešić, także definiowany jest przez dwudziestowieczną inklinację do wędrówek, powodowanych przez czynniki zewnętrzne, takie jak wojna czy napięta sytuacja polityczna. W przeciwieństwie do wcześniejszych wcieleń, współczesny wędrowiec w przymusowej podróży próbuje odnaleźć ukryty sens, co, poza swobodą przemieszczania, stwarza szansę odkrycia i określenia własnej tożsamości; jest „kluczem do poznania i objaśniania świata, kultury oraz roli, jaką odgrywa w nich człowiek"10.

Koncepcja Zygmunta Baumana, kreująca postać turysty i włóczęgi, a inspirowana przez wizerunek Baudelaire'owskiego „przechadzkowicza-oglądacza"11, koresponduje z modelem ponowoczesnego nomady, dotykając także problemu banicji. Autobiograficznie nacechowany podmiot genologicz-

\footnotetext{
6 Zob. A. Grzegorczyk, Anioł po katastrofie, Warszawa 1995, s. 119.

7 Zob. D. Oraić Tolić, Paradigme 20. stoljeća. Avangarda i postmoderna, Zagreb 1996, s. 135.

8 Halina Janaszek-Ivaničková słusznie zauważa, że Słowianie Południowi używają terminu "tranzycja”, pochodzącego od ang. transition - przejście, na oznaczenie okresu przejściowego, tymczasowego, zmierzającego ku czemuś stabilnemu, który w innych krajach słowiańskich znany jest jako "transformacja” (od ang. transformation - przemiana, przekształcenie). Zob. H. Janaszek-Ivaničková, Wstęp, w: Literatury słowiańskie po roku 1989. Nowe zjawiska, tendencje, perspektywy, t. 1, Transformacja, red. H. Janaszek-Ivaničková, Warszawa 2005, s. 11.

9 Zob. K. Wilkoszewska, Wariacje na postmodernizm, Kraków 2000, s. 69.

10 Por. B. Pawletko, Josif Brodski i Tomas Venclova wobec emigracji, Katowice 2005, s. 88-91.

11 Zob. B. Baran, Postmodernizm i końce wieku, Kraków 2003, s. 231.
} 
nie hybrydycznych konstrukcji Ugrešić jest wyrazicielem buntu; to zaciekły nonkonformista, którego opór dotyczy fenomenów rodzimej sceny politycznej, przeszłości federacyjnego państwa czy kontrowersyjnych zjawisk kultury przełomu stuleci. Moment, w którym wychodźstwo zostaje zastąpione przez nomadyzm, jest trudno uchwytny; pisarka, zainteresowana semantycznymi marginesami kulturowej dominanty naszych czasów, balansuje na granicy wspomnianych metafor ponowoczesnej egzystencji. Sytuację komplikuje dodatkowo fakt, iż turysta i włóczęga to byty wzajemnie zależne; "włóczęga jest alter ego turysty", stanowi jego karykaturę ${ }^{12}$.

Wolność, rozumiana jako strategia życiowa, jest dla turysty bezcenna; gwarantuje mu ona mobilność, stwarza poczucie niezależności i autonomii. Taka hierarchia wartości decyduje o odrzuceniu więzów społecznych, nie pozwala związać się z żadnym miejscem; kolejne punkty postoju traktowane są jako obozowiska, a nie potencjalne domostwa. Życie turysty to z założenia epizod bez przeszłości i bez przyszłości; liczy się wyłącznie teraźniejszość. Turysta odrzuca imperatyw tożsamościowy; woli pozostawać „na zewnątrz”, na sposób Baumanowski uznając, że solidnie zbudowana tożsamość wbrew pozorom nie uskrzydla. Zachowując dystans, realizuje potrzebę bezpieczeństwa, co zakrawa na paradoks w obliczu absolutnego braku celu i kresu wędrówki. Jej szlak jest przypadkowy; kluczem do odnalezienia sensu peregrynacji turysty jest jego własna pamięć; to ona pozwala odkryć ukryte znaczenie przebytej drogi, ustalić niegdyś nieobecną logikę przemierzonej trasy. Impulsem do odbycia podróży jest nuda; turysta poszukuje wrażeń, atrakcji, przez co jego wyprawa jest przyjemna. O jej uroku decyduje ponadto dobrowolność; porzucenie miejsca stałego lub tymczasowego pobytu jest chwilowe, a turysta nie jest zagrożony perspektywą niekończącej się tułaczki. Bez względu na uczucia, jakimi go obdarza, posiada on dom, do którego może powrócić i za którym zdarza mu się czasami tęsknić.

W prozie Ugrešić pragnienie domu oznacza tęsknotę za jugosłowiańską przeszłością; to nostalgia, ból bezpowrotnej straty. Wydaje się, że upojenie niezaspokojoną jugonostalgią jest tylko pozornie dobrowolnym wyborem. Nomadyzm Ugrešić naznaczony jest zmęczeniem; jej utwory świadczą o typowo ponowoczesnym wyczerpaniu nieustannym pokonywaniem odległości i kłopotliwym przystosowywaniem się do nowych warunków. Upodobanie do niezobowiązującego stylu życia, charakterystyczne dla turystyki, niezbyt pasuje do sytuacji walczącego o przetrwanie wychodźcy; w opisie tego stanu bardziej pomocne wydają się przymioty włóczęgostwa. Włóczęga wędruje, bo nie ma innego wyboru; „włóczą się” ci, którzy:

12 Zob. Z. Bauman, Ponowoczesność jako źródło cierpień, Warszawa 2000, s. 142-153. 
znaleźli się na drogach, bo ich od tyłu popchnięto, eksmitując z domu, grożąc eksmisją lub czyniąc pozostanie w domu niemożliwym lub nie do zniesienia. Tacy wędrowcy nazwą swą egzystencję rozmaicie, ale miano „wolności” będzie chyba ostatnim, jakie im do głowy przyjdzie. Jeśli już takie pojęcia jak „autonomia” czy „niezależność” pojawią się w ogóle w ich słowniku, to tylko skojarzone z czasem przyszłym. A na razie być wolnym to dla nich tyle, co nie musieć wędrować ${ }^{13}$.

Wędrówka jest dla nich przykrą koniecznością; przymusem, wynikającym $z$ tego, że nigdzie nie są mile widziani. Ich dłuższy pobyt $\mathrm{w}$ jakimś miejscu staje się każdorazowo sprawdzianem gościnności gospodarzy; jego wynik jest, niestety, łatwo przewidywalny. Włóczęga traci pracę i dom, oparcie $\mathrm{w}$ innych okazuje się równie tymczasowe. Chociaż stale przebywa „w drodze", nigdy nie stanie się turystą, bowiem jego tryb życia nie spełnia postulatu wolności wyboru. Wspólnota losu turysty i włóczęgi daje się sprowadzić wyłącznie do braku pewności jutra. Bauman mówi wręcz o „przyrodzonej niepewności ponowoczesnego życia", która dotyczy współcześnie wszystkich; nie istnieją już miejsca, w których ludzie czuliby się bezpiecznie, coraz trudniej o przestrzeń, którą można byłoby określić mianem pełnowartościowego domu ${ }^{14}$. To właśnie wolność wyboru dalszego losu, możliwość kierowania własną przyszłością, jest zmienną, która decyduje o naszym położeniu w kontinuum, określonym przez biegunową opozycję turysta - włóczęga.

W świetle tego ujęcia, podmiot czynności twórczych w prozie Dubravki Ugrešić również sytuuje się na pograniczu. Podobnie jak w przypadku innej pary postmodernistycznych przeciwieństw, trudno byłoby odseparować od siebie wpływy obu figur. Pisarka, skazana na banicję, kontynuuje włóczęgę; $\mathrm{w}$ jej eseistyce i powieściach odnajdujemy ślady kolejnych chwilowych postojów. Wśród miast, takich jak Berlin, Monachium czy Amsterdam, których tekstowe odsłony imponować mogą ponowoczesną różnorodnością, swoistą kontrą dla włóczęgostwa jest Zagrzeb. Obecność w planie podróży aktualnej stolicy Chorwacji jest wytłumaczalna, ale zaprzecza wygnaniu; kwestionując intencjonalne ubezwłasnowolnienie wędrującego. Domniemana swoboda wyboru podważona jednak zostaje przez sentymentalny zwrot ku czasom minionym; posługiwanie się pojęciem "turystyka" wymaga w tym wariancie dookreślenia, bowiem podróżny jest także archeologiem jugosłowiańskiej przeszłości.

\footnotetext{
13 Tamże, s. 149.

14 Tamże, s. 147, 150.
} 
Wieczna opozycjonistka wymyka się kolejnym próbom klasyfikacji. Ramy nowoczesnego dyskursu podróżniczego wydają się zbyt ciasne, aby pomieścić wielowymiarowy obraz dramatycznej ucieczki, specyficznego wypędzenia i niekończącej się tułaczki. Pisarka konsekwentnie uchyla się od obcego jej naturze dyktatu zamanifestowania własnej tożsamości, odwołując się przy tym do prymatu osobistej wolności. Ustalenie sposobu definiowania przez nią niezawisłości oraz możliwości samostanowienia byłoby więc nieocenione dla pełniejszego odczytania dorobku Dubravki Ugrešić w kluczu postmodernistycznych peregrynacji.

\section{Dubravka Ugrešić’s Postmodern Journeys \\ Summary}

In the 1990s Dubravka Ugrešić initiated her ever-continuing journey which may serve as a pretext to analyse the travels characteristic of the break of centuries, undertaken against the background of political transformations in Eastern Europe and the global changes of contemporary culture. The article attempts to outline the writer's emotions brought on by her "expulsion" (her emigration from Croatia), which she expresses in essays and complex novels that witness the postmodern exhaustion of the entitative character. The observations gathered show that the traditional framework of travel discourse is often too narrow to hold the multidimensional image of the dramatic escape, the particular expulsion, and the never-ending wandering. 
